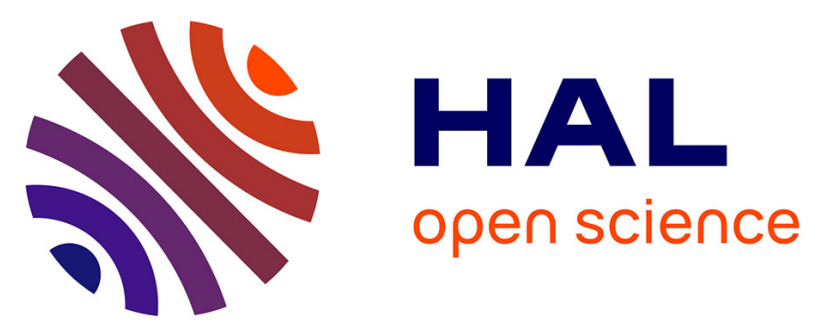

\title{
COMPLEX SHAPE FORMING OF FLAX FABRICS: ANALYSIS OF THE SOLUTIONS TO PREVENT DEFECTS
}

\author{
Emilie Capelle, Pierre Ouagne, D. Soulat, D. Duriatti
}

\section{To cite this version:}

Emilie Capelle, Pierre Ouagne, D. Soulat, D. Duriatti. COMPLEX SHAPE FORMING OF FLAX FABRICS: ANALYSIS OF THE SOLUTIONS TO PREVENT DEFECTS. COMPLEX SHAPE FORMING OF FLAX FABRICS: ANALYSIS OF THE SOLUTIONS TO PREVENT DEFECTS, Jun 2013, Guimaraes, Portugal. pp.47. hal-00838033

\section{HAL Id: hal-00838033 https://hal.science/hal-00838033}

Submitted on 24 Jun 2013

HAL is a multi-disciplinary open access archive for the deposit and dissemination of scientific research documents, whether they are published or not. The documents may come from teaching and research institutions in France or abroad, or from public or private research centers.
L'archive ouverte pluridisciplinaire HAL, est destinée au dépôt et à la diffusion de documents scientifiques de niveau recherche, publiés ou non, émanant des établissements d'enseignement et de recherche français ou étrangers, des laboratoires publics ou privés. 


\title{
COMPLEX SHAPE FORMING OF FLAX FABRICS: ANALYSIS OF THE SOLUTIONS TO PREVENT DEFECTS
}

\author{
Emilie Capelle $^{1,3}$, Pierre Ouagne ${ }^{1(*)}$, Damien Soulat ${ }^{2}$, Davy Duriatti ${ }^{3}$ \\ ${ }^{1}$ Laboratoire PRISME University of Orleans, 8 rue Leonard de Vinci, 45072 Orleans, France \\ ${ }^{2}$ GEMTEX, ENSAIT Roubaix 2 allée Louise et Victor Champier, 59056 Roubaix, France \\ ${ }^{3}$ Groupe Depestele, BP 21, 14540 Bourguebus, France \\ ${ }^{(*)}$ Email: pierre.ouagne@univ-orleans.fr
}

\begin{abstract}
Solutions to preform complex shapes such as a tetrahedron without any defect from flax based woven fabrics are investigated in this work. The first way to prevent the appearance of defects such as tow buckles consists in designing specific woven architecture fabrics. However, even if this solution was shown to be effective on the tetrahedron shape, solutions based on the optimisation of the process parameters to prevent the appearance of buckles from commercial fabrics were also investigated with success.
\end{abstract}

\section{INTRODUCTION}

Nowadays, the market demand for environmentally friendly materials is rapidly increasing. Biodegradable fibres and biodegradable polymers mainly extracted from renewable resources are expected to be a major contribution to the production of new industrial high performance biodegradable composites, partially solving the problem of waste management.

The manufacture and the performance of such materials have already been discussed and it was showed that biodegradable PLLA (L-polylactide acid)/flax fibres mat composites exhibit specific tensile properties equivalent to glass fibre polyester composites [1].

Specific High performance reinforcements are required to manufacture structural or semistructural biocomposite parts. New flax and comingled flax/bioplastic reinforcements have been elaborated in this goal. If large panels have been realised with a good success, the feasibility to manufacture complex shapes part especially with natural fibre based reinforcements without defect needs to be demonstrated.

A sheet forming device has been presented to form severe shapes such as a tetrahedron [2]. Due to the complexity of the shape (triple curvature, low radiuses of curvature etc...), specific defects such as tow buckles and tensile tow defects have been identified [3-4].

To prevent the appearance of these defects, two paths have been identified. The first one consists in optimising the architecture of the fabric. The second one consists in optimising the parameters controlling the forming process.

This work proposes to discuss solutions that were used to prevent the appearance of performing defects.

\section{RESULTS AND CONCLUSIONS}

Solutions to prevent the appearance of buckles based on the optimization of the fabric architecture, either at the scale of the tow or the yarn, or either at the scale of the fabric, were 
presented with success [5]. However, the fabric optimized to prevent the appearance of buckles may not be optimized to prevent the appearance of other defects such as wrinkling. Another solution to prevent the appearance of tow buckles, based on the optimization of the forming parameters, was investigated. This solution is of particular interest as it would enable to use any reinforcement fabric of the market.

To reach this goal, specially optimised blank-holders were machined, and it was shown in Figure 1 that tow buckling could be prevented by only playing on the process parameters. On Figure 1a, the blank holder geometries and pressure are not optimised, and buckles take place. In Figure 1b, the process parameters were carefully chosen, and tow buckles do not appear.

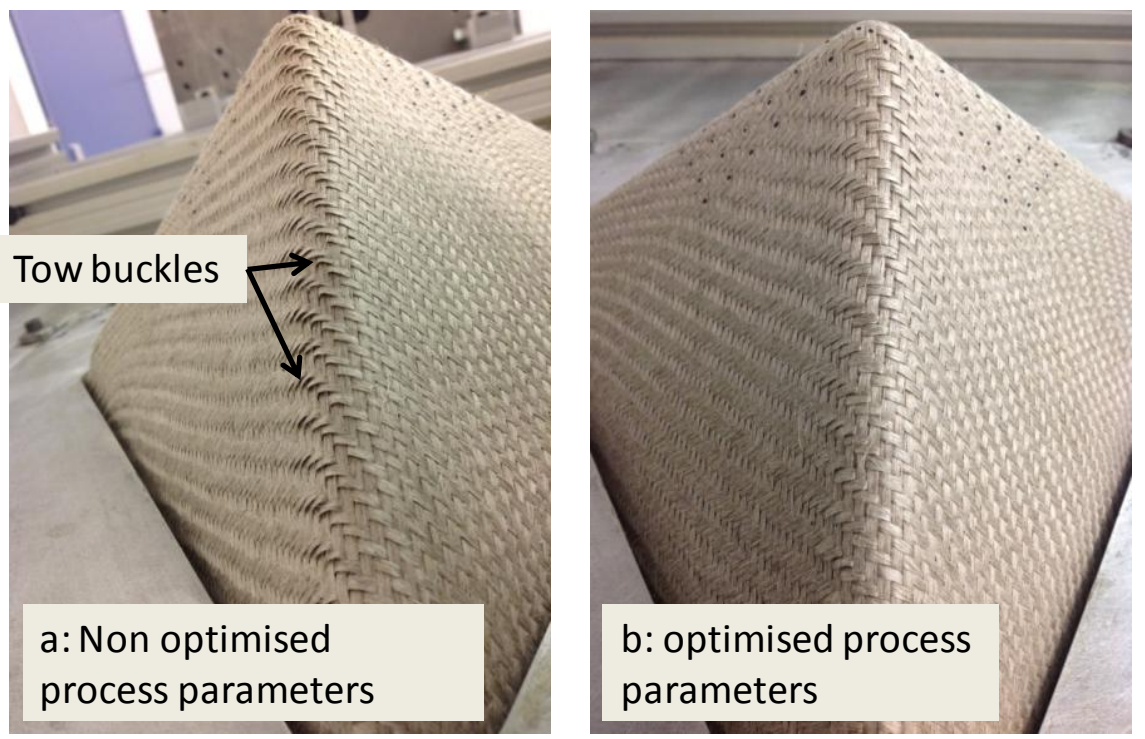

Fig.1 Influence of process parameters on tow buckling

This work demonstrates that it is now possible to prevent the appearance of tow buckles by optimizing the process parameters. It is therefore not necessary to specially optimize the fabric to prevent this defect. As a consequence, a wide range of reinforcements with different architectures can be considered when forming complex shapes such as a tetrahedron.

\section{REFERENCES}

[1] Ouagne P, Bizet L, Baley C, Bréard J. Analysis of the Film-stacking Processing Parameters for PLLA/Flax Fiber Biocomposites. J Compos Mater 2010; 44: 1201-1215.

[2] Ouagne P, Soulat D, Allaoui S, Hivet G."Mechanical properties and forming possibilities of a new generation of flax woven fabrics". Proceeding of the 10th international conference on textile Composite (Texcomp). 26-28 October 2010, Lille, France.

[3] Ouagne P, Soulat D., Hivet G., Allaoui S., Duriatti D. "Analysis of defects during the preforming of a woven flax reinforcement". Advanced Composite Letters, 20 (2011) 105-108.

[4] Ouagne P, Soulat D, Tephany C, Duriatti D, Allaoui S, Hivet G. Mechanical characterisation of flax based woven fabrics and in situ measurements of tow tensile strain during the shape forming. J Compos Mater, doi:10.1177/0021998312467217.

[5] Capelle E, Ouagne P, Tephany C, Soulat D, Duriatti D, Gueret S. Analysis of the tow buckling defect during the complex shape forming of a flax woven fabrics. - Proceedings of the 15TH EUROPEAN CONFERENCE ON COMPOSITE MATERIALS, Venice, Italy, 2428 June 2012. 